\title{
GROWTH OF JUVENILE HORSE'S HOOF CLAMS (Hippopus hippopus) REARED IN COASTAL WATERS, PARI ISLAND, KEPULAUAN SERIBU
}

\author{
L. M. GL Panggabean ${ }^{1}$, S. A. P. Dwiono ${ }^{2}$ and D. E. Djoko Setyono ${ }^{1}$ \\ ${ }^{1}$ Marine Resources Division, Research Center for Oceanography, Jl. Pasir Putih 1 Ancol Timur, Jakarta 14430. \\ ${ }^{2}$ Mataram Marine Bio Industry Technical Implementation Unit, Teluk Kodek, Malaka, Pemenang, Lombok Barat \\ 83352, NusaTenggara Barat.e-mail: sigit_dwiono@yahoo.com
}

\begin{abstract}
The main purpose of this present study is to determine the growth and survival rate of juvenile horse's hoof clams (Hippopus hippopus) and to find out a suitable site for their rearing in nature. Juveniles used in this study were about 3 years old, produced in the hatchery of CV Dinar, Bali. They were reared in the cages, placed on the sea bed at several sites, namely: (1) on the reef flat, (2) on the bed of a lagoon, and (3) on the sea channel. After 360days of rearing, the highest daily growth was found for juveniles reared in site-2, i.e. $0.110 \mathrm{~mm}$ in length, $0.080 \mathrm{~mm}$ in width and $0.091 \mathrm{~mm}$ in height. These values were significantly different from other two sites. The survival rate after 360 days of rearing was $85.5 \%$ in site-1, $99.4 \%$ in site- 2 and $96.8 \%$ in site-3. Based on these results the bed of a lagoon is the best and suitable site to grow horse's hoof clam juveniles in nature. Water condition at this site is relatively calm with sandy-muddy substrates and relatively dense seagrasses, mainly Thallasia spp.
\end{abstract}

Keywords: Horse's hoof clam, Hippopus hippopus, Growth

\section{INTRODUCTION}

Horse's hoof clam \{Hippopus hippopus) is one of the medium size clam called as biagaru in Ambon and kimah pasir in Indonesian. The clam belongs to the genus of Tridacna, and family of Tridacnidae. They live in shallow coastal waters, sessile on a rock, stone and dead coral or anchored itself in a sandy habitat. Horse's hoof clam \{Hippopus hippopus) is mature and release gamete beginning at 5 year-old, and its size about 11-16 cm (Dwiono, 1994).

Horse's hoof clam has very high values in the export market. The adductor muscle is a very delicious and expensive, about US\$30/weight dry weight. The natural population of this clam in Indonesia is very limited, and therefore, the Indonesian Government includes it as threatened species by the Ministerial Decree no. 12/Kpts-II/ 1987. Exception is for clams which seed is produced from hatchery, as regulated by the Ministerial Decree No. 07/Kpts/DJ-VI/1988. Panggabean $(1985,1987)$ reported that the population of horse's hoof clam in Pari Island has dwindled due to over exploitation.

The first successful effort on seed production of clams has been done in the Micronesian Mariculture Demonstration Center in Palau (Heslinga and Perron, 1983). The method was then adopted and improved by some researcher in Australia (Braley, 1984, 1985; Heslinga and Watson, 1985; Braley et al., 1988) and also practiced in Eastern Indonesia (Dwiono, 1994; Braley and Rachman, 1996; Tetelepta and Braley, 1996).

Spawning to produce small size juveniles for export has been successfully carried out in the hatchery of CV. Dinar in Bali. The hatchery produces the juvenile clams to provide for the need of marine aquarium hobbies. However, this successful effort of seed production will also support the reseeding program for depleted areas in Indonesia, to restore the natural population where over exploitation have occurred.

Therefore, in accordance with the reseeding program, the aim of this study is to obtain practical on-growing techniques, especially to gain 
information on the growth and survival rates of juvenile horse's hoof clam and to find the suitable habitat for growing their juveniles in the nature.

\section{MATERIALS AND METHODS}

\section{Cage construction}

To prevent the loss of juveniles caused by predators, juveniles were reared in experiment cages placed in coastal waters of Pari Island. Cages were constructed using a concrete block of $6 \mathrm{~cm}$ thick as a basement, and netting materials of 1 inch mesh size to form a cage of $160 \mathrm{~cm}$ long, by $120 \mathrm{~cm}$ wide, by $20 \mathrm{~cm}$ deep. Similar netting material was used to cover the cage. In order to eliminate possible chemical contamination from netting materials and cement mixtures, cages were submerged in coastal waters of Pari Island at least within 2 weeks before used in the experiment.

\section{Juveniles}

Juveniles used in this study were produced in the hatchery of CV. Dinar in Bali. At the start of the experiment, the clams were about four years old. During the transportation, juveniles were placed horizontally in a Styrofoam box. Old newspaper was set between the layer of clams to keep them in dam condition. The box that was filled with clams was transported from the hatchery at Tembok, Bali to the airport of Denpasar by car and to Jakarta by airplane. On arrival in the
Laboratory of CV Dinar in Tangerang, the box were then unpacked and juveniles were put in containers filled with clean seawater. The first transportation took about 4 hours. After the period of two days, the juveniles were repackaged again and transported by boat to Pari Island. The second transportation took about 7 hours before the clams were taken out to acclimatized in a concrete rectangular tank filled with sea water and finally put in experiment cages. Individuals used in this study have a body or shell, with size ranges of $61.0-113.9 \mathrm{~mm}$ in length, 24.5-62.4 $\mathrm{mm}$ in width and 40.2-74.2 $\mathrm{mm}$ in height.

\section{Treatment and measurement}

Three sites in Pari reef Island were chosen to place the cages. Site- 1 was on a reef moat, site- 2 was on the seagrass bed of Pulau Burung lagoon, and site-3 was on a seagrass bed close to Ciadung Channel (Fig. 1). One cage was set in site- 1 and two cages were set each for site- 2 and site-3 respectively. To avoid a turbidity caused by turbulence water motion, the cages were set 20 $\mathrm{cm}$ above the sea bed.

Each cage was stocked with 80 juveniles. Maximum shell sizes of length, height, and width were measured with vernier caliper having 0.01 $\mathrm{mm}$ scale, at the beginning of the experiment and were repeated every 90 days (Fig. 2). Dead individuals were removed from the cages and the sizes were noted. This study was carried out over 360 days.

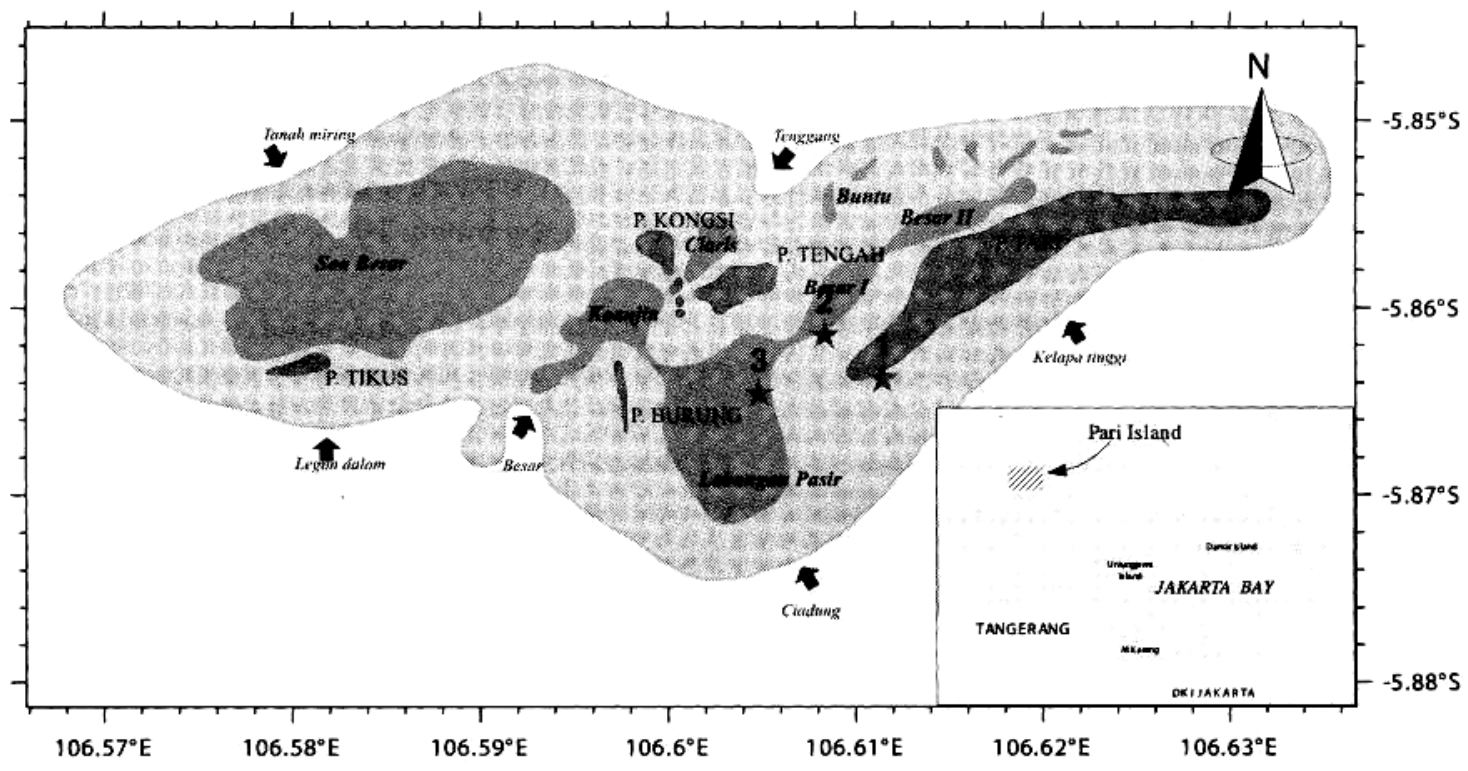

Figure 1. Map of Pari Island showing the study sites 


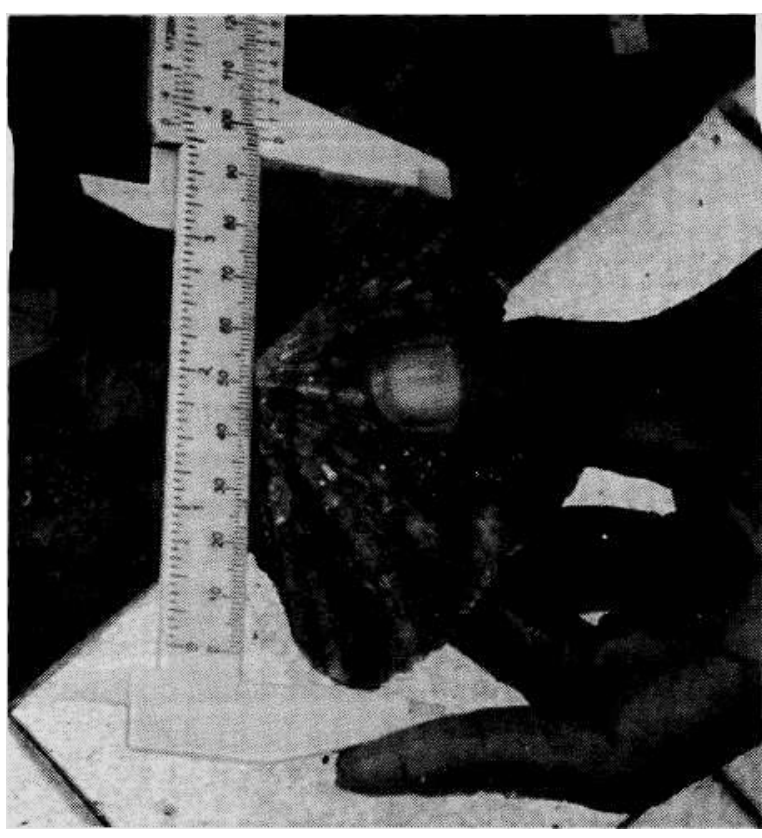

Figure 2. The measurement method for shell length of horse hoof clam \{Hippopus hippopus)

\section{Data analysis}

Cumulative growth (CG), relative growth (RG) and daily growth rate (DG) in shell sizes were calculated as follows:

CG $(\mathrm{mm})=\left(\right.$ shell size at $\left.\mathrm{t}_{\mathrm{n}}\right)-\left(\right.$ shell size at $\left.\mathrm{t}_{0}\right)$ $\mathrm{RG}(\%)=\left[\left(\right.\right.$ shell size at $\mathrm{t}_{\mathrm{n}}$ - shell size at $\left.\mathrm{t}_{0}\right) /$ shell size at $\mathrm{t}_{0}$ ] x $100 \%$
DG $(\mathrm{mm})=$ increase in shell size $(\mathrm{mm}) /$ number of rearing days $=$ rate of growth

where: $t_{n}$ is time of measurement and $t_{0}$ is initial time

The differences in mean initial sizes and mean daily growth rates between juveniles reared at different sites were analyzed using an analysis of variance (ANOVA) without replication. Scheffe post hoc test was used to identify significance differences between the mean values of initial sizes and mean daily growth rates for juveniles reared at different sites. Data were tested for a normal distribution and no transformation was done before the data were analyzed using the ANOVA. The statistical analysis was performed using the software package Data Desk 4.1 (Anonim, 1993). The statistical significance level (P) was set at 0.05 .

\section{RESULTS}

Mean shell sizes at initial and final rearing times, daily growth rate and relative growth is presented in Table 1 . The mean initial sizes were not significantly different $(\mathrm{P}>0.05)$ between sites. The highest daily growth rate is found in site-2, i.e. $0.114 \mathrm{~mm}$ in length, $0.080 \mathrm{~mm}$ in width, and

Table 1. Mean and standard error of shell sizes at initial and final rearing times, and daily growth rates in shell sizes of juvenile Hippopus hippopus reared in cages placed at three different sites of coastal waters, Pari Island. Values without notation are not significantly different between sites $(\mathrm{P}>0.05)$. Values at the same row sharing the same letter are not significantly different $(\mathrm{P}>0.05)$.

\begin{tabular}{|l|c|c|c|}
\hline \multirow{2}{*}{ Variable } & \multicolumn{2}{c|}{ Site } \\
\cline { 2 - 4 } & 1 & 2 & 3 \\
\hline Initial number & 8068 & 160 & 160 \\
Final number & 85.0 & 159 & 155 \\
Survival rate (\%) & & 99.4 & 96.9 \\
\hline Initial shell length (mm) Final shell & $91.78 \pm 1.14^{\mathrm{a}}$ & $91.77 \pm 0.77^{\mathrm{a}}$ & $90.52 \pm 0.76^{\mathrm{a}}$ \\
length (mm) Daily growth rate in shell & $115.59 \pm 1.40^{\mathrm{a}}$ & $132.96 \pm 0.97^{\mathrm{b}}$ & $128.52 \pm 0.95^{\mathrm{c}}$ \\
length (mm) Relative increase in shell & $0.065 \pm 0.001^{\mathrm{a}}$ & $0.110 \pm 0.001^{\mathrm{b}}$ & $0.108 \pm 0.001^{\mathrm{c}}$ \\
length (\%) & $25.50 \pm 0.20^{\mathrm{a}}$ & $45.90 \pm 1.34^{\mathrm{b}}$ & $41.94 \pm 1.29^{\mathrm{b}}$ \\
\hline Initial shell height (mm) Final shell & $61.14 \pm 0.68^{\mathrm{a}}$ & $61.07 \pm 0.46^{\mathrm{a}}$ & $60.00 \pm 0.47^{\mathrm{a}}$ \\
height (mm) Daily growth rate in shell & $78.82 \pm 0.80^{\mathrm{a}}$ & $89.83 \pm 0.53^{\mathrm{b}}$ & $86.98 \pm 0.56^{\mathrm{c}}$ \\
height (mm) Relative increase in shell & $0.046 \pm 0.002^{\mathrm{a}}$ & $0.080 \pm 0.002^{\mathrm{b}}$ & $0.075 \pm 0.002^{\mathrm{c}}$ \\
height (\%) & $28.54 \pm 0.81^{\mathrm{a}}$ & $48.21 \pm 1.28^{\mathrm{b}}$ & $45.15 \pm 1.44^{\mathrm{b}}$ \\
\hline Initial shell width (mm) Final shell & $46.39 \pm 0.73^{\mathrm{a}}$ & $46.36 \pm 0.51^{\mathrm{a}}$ & $47.89 \pm 0.54^{\mathrm{a}}$ \\
width (mm) Daily growth rate in shell & $71.10 \pm 0.85^{\mathrm{a}}$ & $79.81 \pm 0.56^{\mathrm{b}}$ & $75.49 \pm 0.50^{\mathrm{c}}$ \\
width (mm) Relative increase in shell & $0.071 \pm 0.002^{\mathrm{a}}$ & $0.091 \pm 0.002^{\mathrm{b}}$ & $0.079 \pm 0.002^{\mathrm{c}}$ \\
width (\%) & $54.21 \pm 1.85^{\mathrm{a}}$ & $64.56 \pm 1.99^{\mathrm{b}}$ & $59.45 \pm 2.02^{\mathrm{b}}$ \\
\hline
\end{tabular}


$0.093 \mathrm{~mm}$ in height. Changes in mean shell sizes for juvenile horse's hoof clam \{Hippopus hippopus) reared in cages placed at different sites of coastal waters of Pari Island is shown in Figure 3. The figure shown that clam juveniles from site2 have higher growth of shell length, height and width compare to those from other sites.

Figure 4 shows changes in cumulative growth in shell sizes. In general, a juvenile reared at site-2 has the highest cumulative growth than at other sites. Cumulative growth of juvenile horsehoof clam after reared for 360 days at coastal waters, Pari Island were relatively high, i.e. 23-41 mm for shell length, 17-29 mm for shell width and 25 - $33 \mathrm{~mm}$ for shell height.

Relative growth in shell sizes at every 90 days interval is presented in Figure 5. At the first 90 days, juvenile Horse's hoof clam grown at about 8-12\% for shell length, 15-25 \% for shell width and $10-15 \%$ for shell height. At the final study (after 360 days), juvenile Horse's hoof clam grown at about $25-46 \%$ for shell length, 54-65\% for shell width, and $29-48 \%$ for shell height.

Survival rates were relatively high. It is $85.5 \%$ for juveniles reared at site-1, 99.4\% for juveniles reared at site-2, and $96.8 \%$ for juveniles reared at site-3.

\section{DISCUSSION}

Maximization growth is an important factor for successful aquaculture. A variety of factors such as water quality, quantity and quality of food, and stocking density are known to influence the growth of clams (Dwiono and Setyono, 2003). These factors, especially water quality are intimately related with a suitable habitat or site selection where the animals are reared.

At the beginning of the experiment, juveniles used in this study have similar sizes. Changes in cumulative growth during the interval of 90 days measurement (Fig. 4), showed that juveniles reared at site- 2 has the highest cumulative growth, followed by juveniles at site- 3 and 1 although the values are not significantly different. At the end of study (after 360 days), the results show that juveniles reared at site- 2 has a cumulative growth which is significantly different with juveniles at site- 1 but not significantly different with juveniles at site-3. This result shows clearly that site-2 and 3 are suitable location with good habitat for growing juvenile horse's hoof clam. Both sites which covered by seagrassess, mainly Thallasia spp., have quiet water with good circulation where water of Pulau Burung Lagoon passes through Tenggang Channel at the north and Ciadung Channel at the south of the reef of Pari Island. Healthy and good exchange rate of the lagoon water has shown by reported dissolved oxygen (DO) condition from the lagoon which commonly ranged from 6.61-8.67 during neap and 5.1-7.58 during low tide (Rochyatun, 2002).

Water quality of the reef in general is within the range tolerance for the clams. Besides DO, Rochyatun (2002) also reported varieties of salinity, temperature and $\mathrm{pH}$ of 13 stations in the reef in July 1999, October 1999 and February 2000. Salinity ranged 28-35 psu and 27-34 psu during low tide. Temperature ranged $28-32.4^{\circ} \mathrm{C}$ during neap and $27.1-32.4^{\circ} \mathrm{C}$ during low tide. $\mathrm{Ph}$ ranged 7.89-8.86 during neap and 7.08-8.94 during low tide.

One of the reasons that the juveniles in site- 1 has the lowest growth can be explained as follows. Site-1 located about $50 \mathrm{~m}$ from the reef slope. The seafloor consisted of coral rubble and sandy substrate. Water movement at site- 1 is relatively rough during bad weather and during the time when the tide is rising. This unfavorable condition is supposed to limit juveniles to open their mantle. This fact caused the symbiotic algae or zooxanthela (Symbiodinium microadriaticum) which live in the mantle of the clams can not maximize their photosynthesis to provide sufficient food for the clams to grow.

The growth results indicated that horse's hoof clams require areas with quiet and good circulation water to support their growth. Areas with strong water movement can retard normal growth in shell length. 

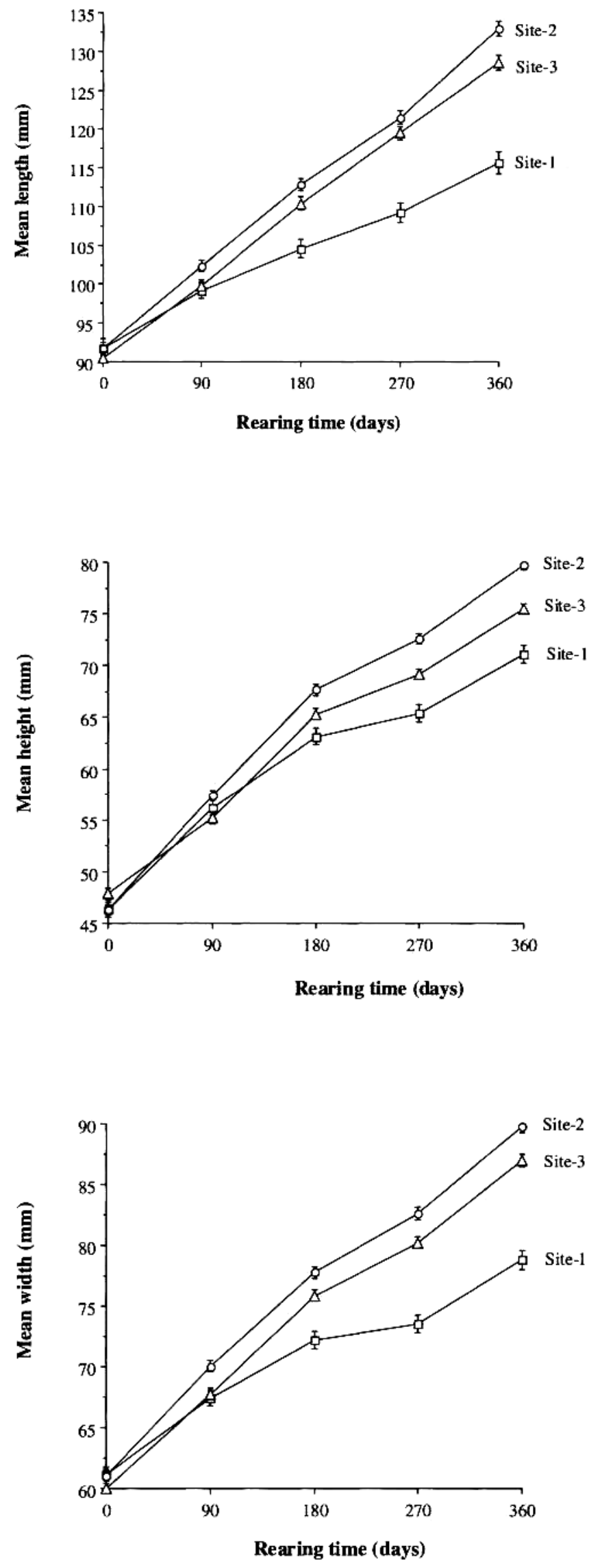

Figure 3. Mean shell sizes 

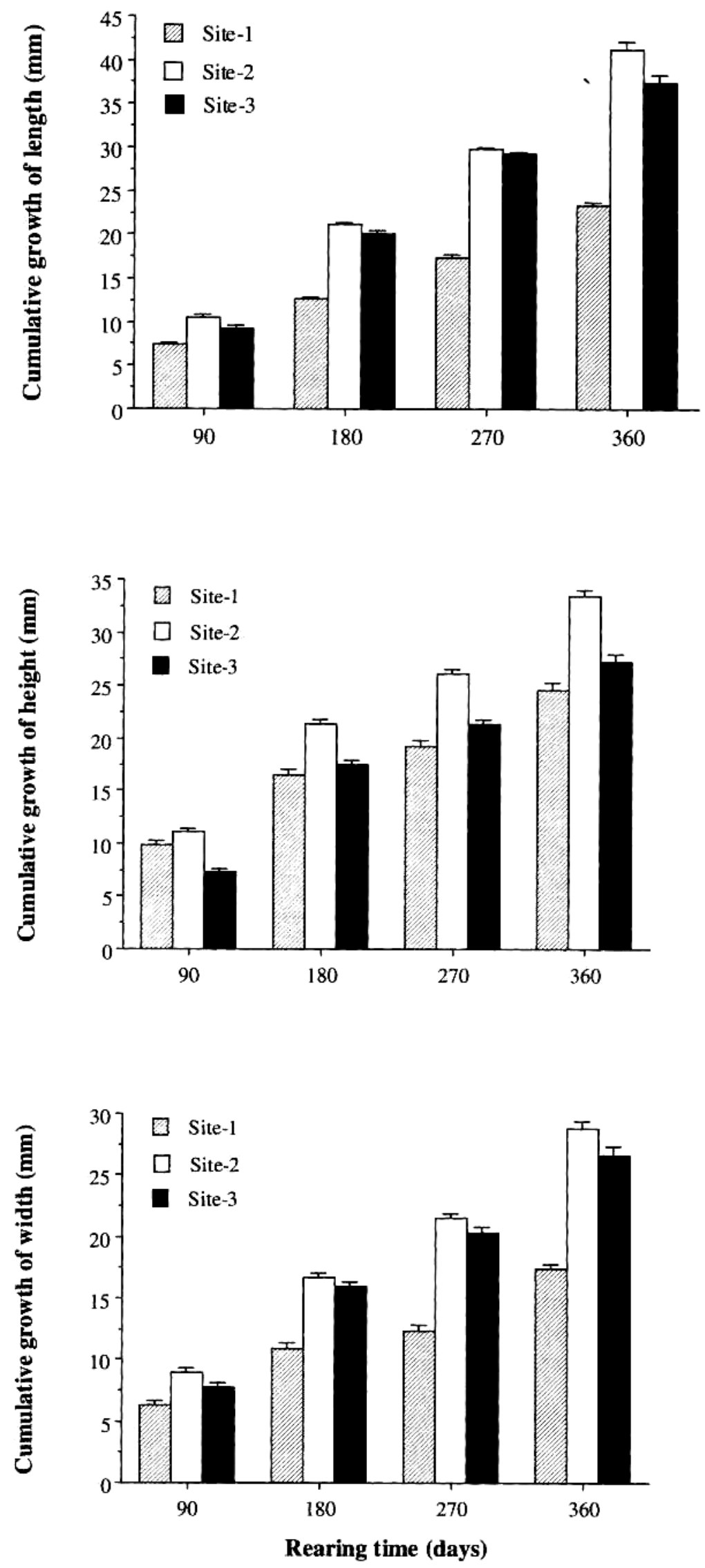

Figure 4. Cumulative growth 

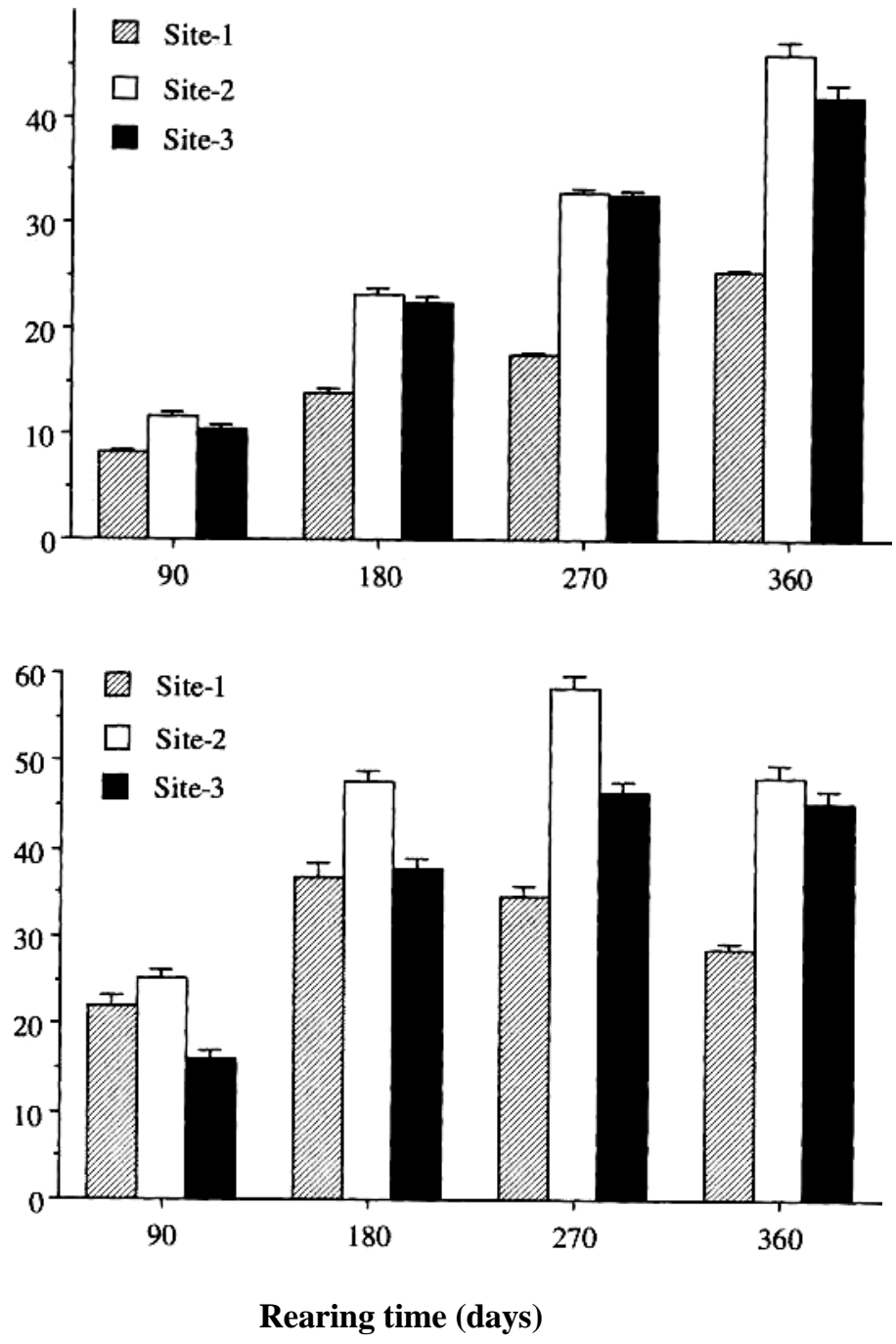

Figure 5. Relative growth of shell size 


\section{REFFERENCES}

Anonim 1993. Statistical software for Macintosh. Data description, Inc. New York, USA.

Braley, R.D. 1984. Reproduction in the giant clams Tridacna gigas and Tridacna derasa in situ on the North Central Great Barrier Reef and Papua New Guinea. Coral Reefs, 3:221-227.

Braley, R.D. 1985. Serotonin -induced spawning in giant clams (Bivalvia: Tridacnidae). Aquaculture, 47:321325.

Braley, R.D., W.J. Nash, J.S. Lucas and C.M. Crawford 1988. Comparison of different hatchery and nursery methods for the giant clams Tridacna gigas. In: Giant clams in Asia and the Pacific (J.W. Copland and J. S. Lucas, eds). Pp: 110-114.

Braley, R.D and A. Rachman 1996. A successful protocol for the hatchery and land nursery of giant clams (Fam. Tridacnidae). Perairan Maluku dan Sekitarnya, 19: 81-85.

Dwiono, S.A.P. 1994. Pemijahan buatan dan pemeliharaan larva Tridacna squamosa (Lamark) dan Hippopus hippopus (Linnaeus) di laboratorium: Suatu hasil pendahuluan. Perairan Maluku dan Sekitarnya, 8: 23-33.

Dwiono, S.A.P. and Setyono, D.E.D. 2003. Stocking density and growth of juvenile green snail (Turbo marmoratus) cultured in cages placed on intertidal area. Paper presented at Pertemuan ilmiah tahunan Ikatan Sarjana Oseanologi Indonesia Jakarta, 10-11 December 2003.

Heslinga. G.A. and F.E. Perron 1983. The status of giant clam mariculture technology in the Indo Pacific. South Pacific Commission Fisheries Newsletter, 24. January-March. 5 pp.

Heslinga, G.A. and T.C. Watson 1985. Recent advances in giant clam mariculture. Proceeding for an International Congress. Coral Reefs 5: 531-537.

Panggabean, L.M.G. 1985. Keadaan stok kimah (Tridacnidae) di Pulau Pari, Pulau-pulau Seribu. Makalah disampaikan pada Kongres Nasional Biologi Indonesia VII. Palembang, 29-31 Juli 1985.

Panggabean, L.M.G. 1987. The status of tridacnid clam and its preliminary culture stock on Pari Island. BIOTROP Special Publication, 30: 53-62.

Rochyatun, E. 2002. Variasi musiman kandungan oksigen terlarut di Perairan Gugus Pulau Pari. In Perairan Indonesia: Oseanografi, Biologi dan Lingkungan (Ruyitno et al., eds). 23-32

Tetelepta, C. H. A. and R. D. Braley 1996. Growth and survival of the giant clam Tridacna derasa in a pond with subsequent release to ocean nursery culture in eastern Indonesia. Perairan Maluku dan Sekitarnya, 19:71-79. 